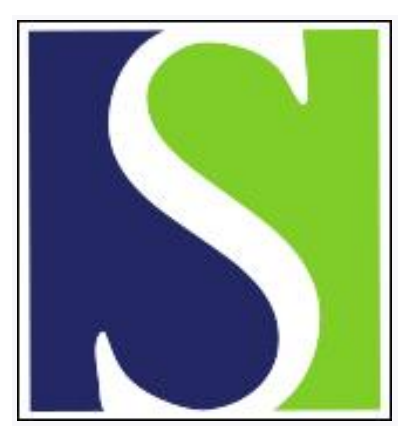

Scand J Work Environ Health 1996;22(3):197-203

https://doi.org/10.5271/sjweh.131

Issue date: Jun 1996

\title{
Occupational injuries in the Finnish furniture industry
}

by Aaltonen MVP

Key terms: accident investigation; accident research; accident statistics; Finland; furniture industry; injury; manufacturing of nonmetal furniture; Nordic cooperation; occupational injury; occupational safety; occupational safety and health; potential injury

This article in PubMed: www.ncbi.nlm.nih.gov/pubmed/8837265

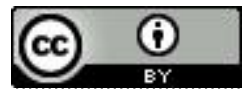




\title{
Occupational injuries in the Finnish furniture industry
}

\author{
by Markku VP Aaltonen, LicTech'
}

\begin{abstract}
Aaltonen MVP. Occupational injuries in the Finnish furniture industry. Scand J Work Environ Health 1996;22: $197-203$.
\end{abstract}

\begin{abstract}
Objectives The purpose of the study was to determine the types of occupational injuries that occur in the Finnish furniture industry and to see whether they differ as regards production type and company size.

Methods During a one-year registration period accident events, the actual and potential severity of the injuries, the causes of the accidents, and the measures needed to prevent such accidents were examined in 18 Finnish furniture factories of different types. An analysis of covariance determined the variables affecting the actual and potential severity of the injuries.

Results The 214 accidents registered were lost-time injuries; two of them resulted in slight partial loss of fingertips. The disabling injury rate was 14.4 per 100 workers per year. Wooden furniture production and kitchen cupboard production in large companies had the highest rate. Accidents involving machines comprised half of the material. Saws were the most common machine type. Forty-two percent of the injuries could have been more severe; one injury could have been fatal. The injured persons and their foremen identified the causal factors of the accidents and the needed safety countermeasures well. Sixty-six percent of the causes and $65 \%$ of the safety countermeasures were associated with the actions of the workers and the workplace procedures. Nevertheless, only $6 \%$ of the identified safety countermeasures were put into force.

Conclusions It was estimated that, in 1987, 2000 on-site accidents leading to at least first-aid at some health care center occurred in the Finnish furniture industry. Special efforts should be taken to improve safety in furniture production in Finland.
\end{abstract}

Key terms accident investigation, accident research, accident statistics, manufacturing of nonmetal furniture, Nordic cooperation, occupational safety, potential injury.

The manufacture of furniture has been recognized as a hazardous branch of industry (1-5). In North Carolina, the leading furniture manufacturing state in the United States, the most common work-related problems have been noise, dust, machine accidents, chemical vapors, materials handling, and poor housekeeping (1). Especially hazards in the handling of chemicals have been reported $(6,7)$.

Because of the numerous work environment hazards, safety and health guides and standards have been published in varjous countries for use by the furniture industry $(8-10)$.

As a part of a Nordic research project (11), Söderqvist \& Persson (12) studied occupational accidents in 19 Swedish furniture factories. During the one-year follow-up, 146 injuries were reported, and the disabling injury rate was 6 injuries per 100 workers per year. In the corresponding Nordic study in Norway (13), the disabling injury rate was 6.7 accidents per 100 workers in a year in 20 furniture factories.
Occupational injuries have not been studied much in the Finnish furniture industry. The disabling injury rate of Finnish furniture carpenters was found to be lower than that of house carpenters, but it was nevertheless higher than the average accident rate in the entire industry (3). In another study (14), saws, planes, milling machines, drills, and grinding machines were found to cause most of the injuries in the manufacture of nonmetallic furniture.

The Finnish furniture industry experienced an economic boom in 1987; in the same year 1019 occupational accidents occurred that caused at least $3 \mathrm{~d}$ of absenteeism from work. The accident rate (8.4 accidents per 100 workers per year) was slightly higher than that of all industrial branches (15).

On the basis of the present study, it was estimated that, in 1987, 2000 workplace accidents leading to at least first aid at some health care center occurred in the Finnish furniture industry. About a half of these injuries resulted in at least $3 \mathrm{~d}$ of incapacity to work and were

1 Finnish Institute of Occupational Health, Department of Occupational Safety, Safety Information Systems, Vantaa, Finland.

Reprint requests to: Mr Markku Aaltonen, Finnish Institute of Occupational Health, Department of Occupational Safety, Safety Information Systems, Laajaniityntie 1, FIN-01620 Vantaa, Finland. 
registered in the official accident statistics of Finland. The disabling injury rate of the Finnish furniture industry was double that of the Swedish and Norwegian furniture industry, although the production technology is similar in these countries (11). This difference indicates that the safety culture of the furniture industry is not parallel in the Nordic countries. The accident risk also varies in the furniture industry according to production type and company size. Since minor accidents entail a potential risk for more severe injury, nondisabling injuries (ie, those requiring only first-aid and medical treatment) should be followed also at the company level. This information should be valuable for accident prevention. In order to ensure the competitivity and the health of the workers in the Finnish furniture industry, efforts should be taken to improve the safety of furniture production to at least the same level as in the other Nordic countries.

The objective of this study was to determine the type of work injuries that occur in the Finnish furniture industry and to determine whether they differ as regards production type and size of company. Another goal was to reveal the factors affecting the severity of injuries and the potential injury risk.

\section{Materials and methods}

The occupational injuries were investigated in the participating furniture factories during the course of 12 months (in 1986-1987). All occupational accidents which took place during workhours and which prompted at least first-aid treatment at a medical facility were investigated. Commuting accidents between the home and workplace were not included, nor were injuries which resulted from prolonged strain.

Eighteen furniture firms (table 1) were selected for study on the following bases (16): the company manufactured nonmetallic furniture; the company was a member of the employers' association; the factory was located in the Lahti business region (three were located elsewhere in southern Finland however); the company fell into one of the following size categories: (i) $20-49$ workers, (ii) $50-200$ workers, or (iii) over 200 workers; the company represented at least one of the following production types: (i) wooden furniture (such as tables, chairs, cabinets), (ii) upholstery (such as sofas, armchairs), or (iii) kitchen cupboards.

The follow-up covered a total of 1482 workers and 71 foremen and involved about $13 \%$ of the total Finnish furniture industry. The follow-up of injuries in the large companies was restricted to the department which represented one of the aforementioned production types. Three companies engaged in both wooden furniture and upholstery (combined) production. One company was dissolved due to bankruptcy two months before the end of the follow-up period.

Injury data were collected from the companies' internal accident report forms and their accident information forms to insurance companies. The injured persons and their foremen were also interviewed after the injured persons had returned to work. A special questionnaire form was prepared for the interviews.

The following safety performance indices were calculated: the number of disabling injuries, the disabling injury rate (number of disabling injuries per 100 workers per year), the severity of injuries (total days of sick leave per number of disabling injuries), the average days of sick leave per worker per year due to injuries.

The accident analysis was based on the Finnish accident investigation method (17), which is a variant of multilinear process models in which an accident is seen as a flow of events. The domino theory of Heinrich et al (18) was an early variant which modeled an accident as a one-dimensional sequence of events. The multilinear event-sequencing method models the process resulting in an injury as a sequence of events made up of interactions between various actors of the system $(19,20)$. The Finnish model considers two actors, the action of the injured person and the action of the source of injury (17).

Altogether 23 variables were investigated for each injury. The variables included data on the injured person, the events preceding the accident sequence, the accident sequence, the injury sequence, and the safety measures needed to prevent such accidents. The categories of variables were selected as suitable for Nordic

Table 1. Number of furniture factories and of workers involved in the study according to production type and company size.

\begin{tabular}{|c|c|c|c|c|c|c|c|c|c|c|c|}
\hline \multirow[t]{3}{*}{ Company size } & \multicolumn{8}{|c|}{ Type of furniture production } & \multirow{2}{*}{\multicolumn{3}{|c|}{$\begin{array}{l}\text { Total } \\
\text { Workers }\end{array}$}} \\
\hline & \multicolumn{2}{|c|}{ Wooden } & \multicolumn{2}{|c|}{ Uphotstery } & \multicolumn{2}{|c|}{ Combined } & \multicolumn{2}{|c|}{ Kitchen } & & & \\
\hline & $\begin{array}{l}\text { Fac- } \\
\text { tories } \\
\text { (N) }\end{array}$ & $\begin{array}{l}\text { Work- } \\
\text { ers } \\
\text { (N) }\end{array}$ & $\begin{array}{l}\text { Fac- } \\
\text { tories } \\
(\mathbb{N})\end{array}$ & $\begin{array}{l}\text { Work- } \\
\text { ers } \\
\text { (N) }\end{array}$ & $\begin{array}{l}\text { Fac- } \\
\text { tories } \\
(\mathrm{N})\end{array}$ & $\begin{array}{l}\text { Work- } \\
\text { ers } \\
\text { (N) }\end{array}$ & $\begin{array}{l}\text { Fac- } \\
\text { tories } \\
(\mathrm{N})\end{array}$ & $\begin{array}{l}\text { Work- } \\
\text { ers } \\
\text { (N) }\end{array}$ & $\begin{array}{l}\text { Fac- } \\
\text { tories } \\
(\mathrm{N})\end{array}$ & $\mathrm{N}$ & $\%$ \\
\hline $\begin{array}{l}20-49 \text { workers } \\
50-200 \text { workers } \\
>200 \text { workers }\end{array}$ & $\begin{array}{l}4 \\
2 \\
2 \\
\end{array}$ & $\begin{array}{l}128 \\
203 \\
200\end{array}$ & $\frac{2}{2}$ & $\frac{63}{252}$ & $\begin{array}{l}1 \\
1 \\
1\end{array}$ & $\begin{array}{r}40 \\
65 \\
180 \\
\end{array}$ & $\begin{array}{l}- \\
2 \\
1\end{array}$ & $\begin{array}{r}-\overline{216} \\
135 \\
\end{array}$ & $\begin{array}{l}7 \\
5 \\
6 \\
\end{array}$ & $\begin{array}{l}231 \\
484 \\
767\end{array}$ & $\begin{array}{l}15 \\
33 \\
52\end{array}$ \\
\hline Total & 8 & $531(36 \%)$ & 4 & $315(21 \%)$ & 3 & $285(19 \%)$ & 3 & $351(24 \%)$ & 18 & 1482 & 100 \\
\hline
\end{tabular}


Table 2. Number of occupational injuries, the disabling injury rate, the severity of injuries, and the number of days of sick leave per worker per year in the furniture factories according to production type and company size.

\begin{tabular}{|c|c|c|c|c|c|c|c|c|c|c|c|c|c|c|c|c|c|c|c|}
\hline \multirow{3}{*}{$\begin{array}{l}\text { Company } \\
\text { size }\end{array}$} & \multicolumn{16}{|c|}{ Type of furniture production } & \multicolumn{3}{|c|}{ Total } \\
\hline & \multicolumn{4}{|c|}{ Wooden } & \multicolumn{4}{|c|}{ Upholstery } & \multicolumn{4}{|c|}{ Combined } & \multicolumn{4}{|c|}{ Kitchen } & \multirow[b]{2}{*}{$\begin{array}{c}\text { Occupa- } \\
\text { tional } \\
\text { injuries } \\
(\mathrm{N})\end{array}$} & \multirow[b]{2}{*}{$\begin{array}{l}\text { Dis- Severity } \\
\text { abling of } \\
\text { injury inju- } \\
\text { rate }^{\mathrm{a}} \text { ries }\end{array}$} & \multirow[b]{2}{*}{$\begin{array}{l}\text { Sick } \\
\text { leave }\end{array}$} \\
\hline & $\begin{array}{l}\text { Occupa- } \\
\text { tional } \\
\text { injuries } \\
(\mathrm{N})\end{array}$ & $\begin{array}{l}\text { - Dis- } \\
\text { abling } \\
\text { injury } \\
\text { rate }\end{array}$ & $\begin{array}{c}\text { Severity } \\
\text { of } \\
\text { inju- } \\
\text { ries }^{b}\end{array}$ & $\begin{array}{l}\text { Sick } \\
\text { leave }^{\circ}\end{array}$ & $\begin{array}{c}\text { Occupa- } \\
\text { tional } \\
\text { injuries } \\
(\mathrm{N})\end{array}$ & $\begin{array}{l}\text { Dis- } \\
\text { abling } \\
\text { injury } \\
\text { rate }^{2}\end{array}$ & $\begin{array}{l}\text { Severity } \\
\text { of } \\
\text { inju- } \\
\text { ries }^{b}\end{array}$ & $\begin{array}{l}\text { Sick } \\
\text { leavec }\end{array}$ & $\begin{array}{l}\text { Occupa- } \\
\text { tional a } \\
\text { injuries i } \\
\text { (N) }\end{array}$ & $\begin{array}{l}\text { Dis- } \\
\text { abling } \\
\text { injury } \\
\text { rate }^{a}\end{array}$ & $\begin{array}{c}\text { Severity } \\
\text { of } \\
\text { inju- } \\
\text { ries }^{b}\end{array}$ & $\begin{array}{l}\text { Sick } \\
\text { leavec }\end{array}$ & $\begin{array}{l}\text { Occupa- } \\
\text { tional } \\
\text { injuries } \\
(\mathrm{N})\end{array}$ & $\begin{array}{l}\text { Dis- } \\
\text { abling } \\
\text { injury } \\
\text { rate }\end{array}$ & $\begin{array}{c}\text { Severity } \\
\text { of } \\
\text { inju- } \\
\text { ries }^{b}\end{array}$ & $\begin{array}{l}\text { Sick } \\
\text { leave }\end{array}$ & & & \\
\hline $\begin{array}{l}20-49 \text { workers } \\
50-200 \text { workers } \\
>200 \text { workers }\end{array}$ & $\begin{array}{l}13 \\
35 \\
50\end{array}$ & $\begin{array}{l}10.2 \\
17.2 \\
25\end{array}$ & $\begin{array}{r}13 \\
11 \\
6\end{array}$ & $\begin{array}{l}1.3 \\
1.9 \\
1.5\end{array}$ & $\frac{5}{28}$ & $\frac{7.9}{11.1}$ & $\frac{8}{7}$ & $\frac{0.6}{0.8}$ & $\begin{array}{r}3 \\
1 \\
15\end{array}$ & $\begin{array}{l}7.5 \\
1.5 \\
8.3\end{array}$ & $\begin{array}{r}4 \\
10 \\
12\end{array}$ & $\begin{array}{l}0.3 \\
0.2 \\
1.0\end{array}$ & $\begin{array}{l}\overline{33} \\
31\end{array}$ & $\begin{array}{l}15.3 \\
23.0\end{array}$ & $\begin{array}{r}\overline{10} \\
5\end{array}$ & $\begin{array}{l}\overline{1.5} \\
1.2\end{array}$ & $\begin{array}{r}21 \\
69 \\
124\end{array}$ & $\begin{array}{cc}9.1^{\star \star} & 11 \\
14.3^{* *} & 11 \\
16.2^{\star *} & 7\end{array}$ & $\begin{array}{l}1.0 \\
1.6 \\
1.1\end{array}$ \\
\hline Total & $\begin{array}{c}98 \\
(46 \%)\end{array}$ & $18.5^{*}$ & $* * *$ & 1.7 & $\begin{array}{c}33 \\
(15 \%)\end{array}$ & $10.5^{*}$ & ** 7 & 0.7 & $\begin{array}{l}19 \\
(9 \%)\end{array}$ & $6.7^{\star \star}$ & ** 10 & 0.7 & $\begin{array}{c}64 \\
(30 \%)\end{array}$ & 18.2 & 8 & 1.5 & $\begin{array}{c}214 \\
(100 \%)\end{array}$ & 14.4 & 1.2 \\
\hline
\end{tabular}

Injuries per 100 workers per year.

Days of sick leave per injury.

Number of days of sick leave per worker per year.

furniture factories $(11,16)$. The information on the identified accident causes and the needed safety countermeasures was obtained by interviewing the injured persons and their foremen. The injured persons were asked what the most severe potential injury after the accident might have been. The severity classification developed by Laitinen (21) was used in this evaluation.

The statistical methods used were multidimensional cross-tabulations and an analysis of covariance for testing which variables affect the actual severity and the potential severity of the injury. The variable sick-leave days was transferred into a logarithmic variable because the dependent $y$-variable should have been normally distributed in the analysis of covariance. An interaction analysis and a residual analysis were carried out as additional tests (22). Poisson regression was used to model count data (number of injuries) with person-time type denominators (number of workers per year). The model linked the count and the rate multiplier (denominator) with a set of fixed covariate values (type of production and company size). The basic assumption of this model is that the occurrence of an accident obeys the Poisson distribution (23). The chi-square test was used to test the differences of the values in cross-tabulation. SAS software (version 6.08) in a Windows environment (24) and EGRET software (23) were used for the statistical analyses.

The study material and the furniture industry accidents from the official work accident statistics in 1987 (15) were compared with each other for the evaluation of external validity to see whether the conclusions based on the results could be generalized to include the entire furniture industry. The comparison was made according to the linear distributions of source of injury. The study material was also comparable with the Swedish (12) and Norwegian (13) material, as accident data were collected with similar methods in the Nordic cooperative study (11) of furniture factories.

\section{Results}

\section{Safety performance indices}

During the one-year follow-up, 214 occupational injuries were registered which led to at least first-aid treatment in some health care center. The injuries were clustered into wooden furniture and kitchen cupboard production (table 2). The disabling injury rate was 14.4 injuries per 100 workers per year. The injury rates differed in regard to production type $(\mathrm{P}<0.001)$ and company size $(\mathrm{P}<0.01)$ (table 3$)$. The highest rates were found in the manufacture of wooden and kitchen furniture of large companies. The disabling injury rate in upholstery work was smaller than the rate in wooden furniture production $(\mathrm{P}<0.001)$. The lowest rate was found in factories with combined production (versus wooden furniture production only $\mathrm{P}<0.001$ ). Considering only company size, small companies had the lowest disabling injury rate and large companies had the highest $(\mathrm{P}=0.004)$. The most severe

Table 3. Poisson regression analysis of the occupational injuries that occurred in the furniture factories.

\begin{tabular}{lcccc}
\hline Variable & $\begin{array}{c}\text { Disability } \\
\text { injury } \\
\text { rate }^{\mathrm{a}}\end{array}$ & $\begin{array}{c}\text { Crude } \\
\text { rate } \\
\text { ratio }\end{array}$ & $\begin{array}{c}\text { Adjusted } \\
\text { rate } \\
\text { ratio }\end{array}$ & P-value $^{\mathrm{b}}$ \\
\hline $\begin{array}{l}\text { Type of production } \\
\mathrm{P}<0.001^{\mathrm{d}}\end{array}$ & & & & \\
$\quad$ Wooden & 18.5 & 1.00 & 1.00 & \\
$\quad$ Upholstery & 10.5 & 0.57 & 0.4718 & $<0.001$ \\
$\quad$ Combined & 6.7 & 0.36 & 0.3173 & $<0.001$ \\
$\quad$ Kitchen & 18.2 & 0.98 & 0.9371 & 0.696 \\
Company size & & & & \\
P<0.01d & & & & \\
$\quad$ Small & 9.1 & 1.00 & 1.00 & \\
$\quad$ Medium & 14.3 & 1.57 & 1.314 & 0.295 \\
$\quad$ Large & 16.2 & 1.78 & 2.002 & 0.004 \\
\hline
\end{tabular}

a Number of injuries per 100 workers per year

- Disabling injury rate divided by the disabling injury rate of the first category of the variable.

- Test for the hypothesis that the adjusted rate ratio is 1 .

d Test for the hypothesis that all the adjusted category rate ratios of the variable are 1. 
injuries occurred in the wooden furniture production of small companies, although these companies had a lower disabling injury rate than the rate of all companies. The sick leaves, on the other hand, were shorter in the large companies than in the small or medium-sized ones.

\section{Accident analysis}

The injured persons most often worked with machines or handled materials. Four main types of accidents were found, covering $91 \%$ of all types of accidents (figure 1). The accident types did not differ, however, in regard to production type $(\mathrm{P}=0.534)$. Cuts and contusions of a finger and back strain were the most common injuries, comprising $52 \%$ of all injuries. Various hand injuries accounted for $61 \%$ of all injuries.

Machines were involved in 110 injuries $(51 \%$ of all injuries). The most common types of involved machines were $(N=110)$ saws, such as circular, band, multiple edging, dimensional circular, and cross-cutting saws (23\%); boring and milling machines $(21 \%)$; grinders $(8 \%)$; machine lines and combination machines $(6 \%)$; planes $(6 \%)$; gluing and composition machines $(6 \%)$; others $(30 \%)$.

Men were injured in 153 cases $(71 \%)$. The average age of the injured persons was 35 (SD 11.7) years, being 32 years for the men and 41 years for the women. The proportion of young workers among the injured was relatively high; $29 \%$ were under 25 years of age. The inju- ries of young workers were generally not severe, especially those under 20 years of age (average $4 \mathrm{~d}$ of sick leave per injury, $\mathrm{N}=26$ ).

At least one accident causal factor was identified for 175 injuries ( $82 \%$ of all injuries), and two causal factors were found for 29 injuries (13\%). A total of 233 accident causal factors were identified (ie, an average of 1.1 causal factors per injury). Forty-five percent of the causal factors involved unsafe acts of workers, and $21 \%$ were related to deficiencies in workplace procedures. Onethird of the causal factors involved deficiencies in the technology and work environment. The causal factors differed according to accident types (table 4).

\section{Actual and potential severity of injuries}

The total of sick leaves for all 214 injuries amounted to 1796 days, including weekends; an average of 8.4 days per injury (standard deviation 12.4). The longest sick leave lasted 92 days. The registered 186 injuries were temporary total disabilities (requiring more than one day's sick leave), including two cases involving slight partial loss of fingertips. Thirteen percent of the injuries needed medical treatment only (less than one day's sick leave).

The following variables affected the actual severity of injuries the most (table 5): type of injury (fractures, loss of fingertips, other), injured part of body (shoulders or arms, chest, back), production type (combined pro-
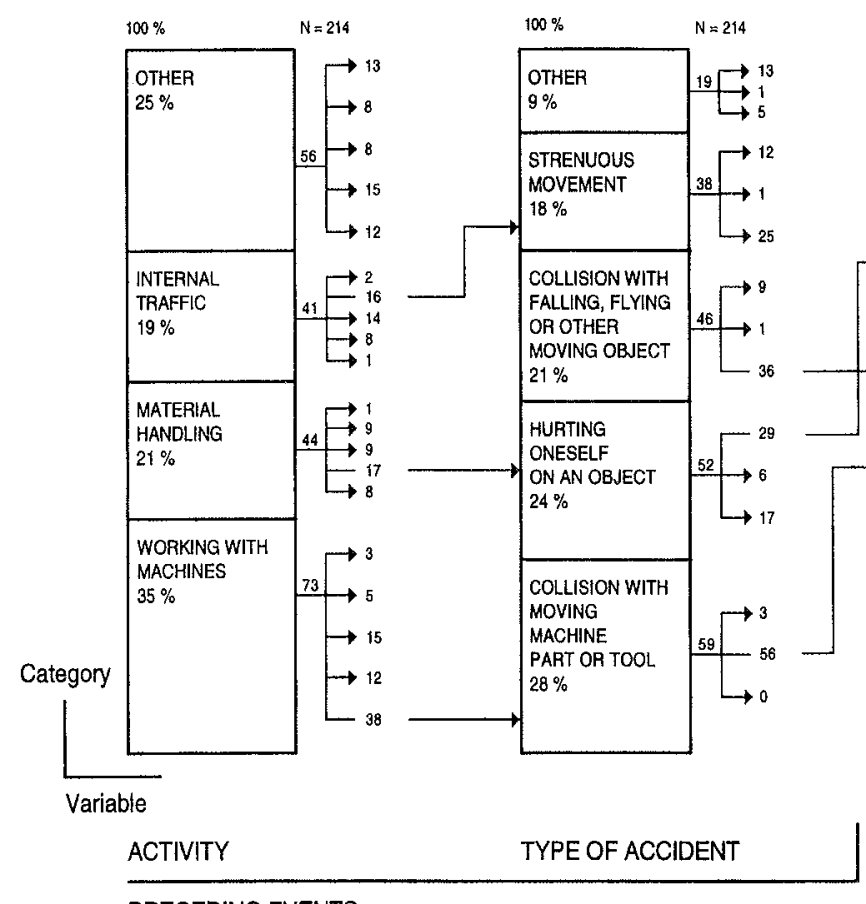

PRECEDING EVENTS

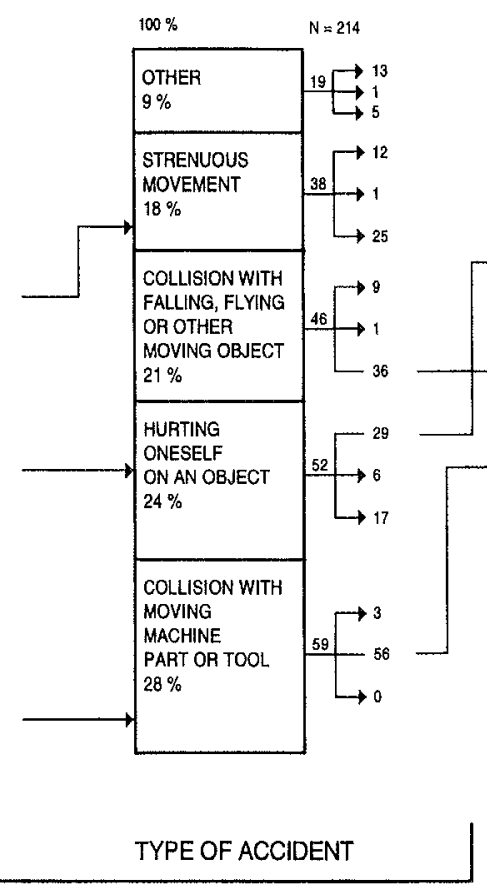

Phases of accident process
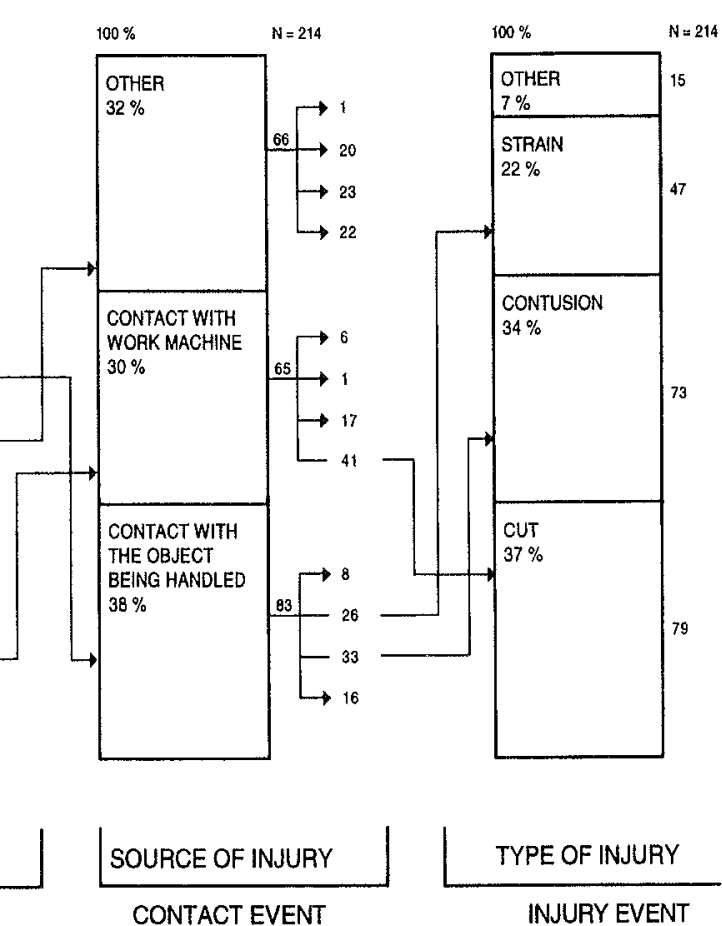

Figure 1. Distribution of the main variables and event chains of the occupational injuries that occurred in the furniture factories $(N)=$ number of injuries). 
Table 4. Accident causal factors according to accident type in the furniture factories.

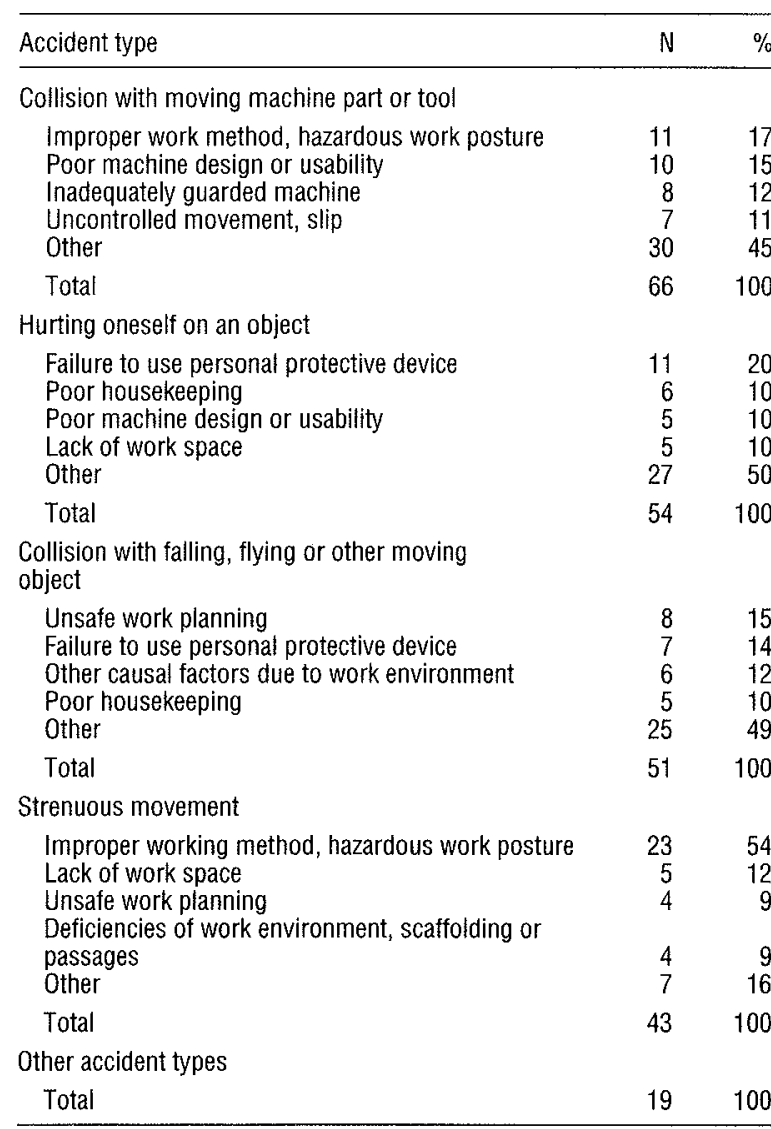

duction), and company size (medium-sized). The shorter the period of service of the injured person, the more severe the injury, but in this material it was not quite statistically significant $(\mathbf{P}=0.067)$.

According to the views of the injured persons, $42 \%$ of all injuries might have led to an even more severe injury (table 6). Altogether $67 \%$ of the minor injuries (less than $3 \mathrm{~d}$ of sick leave) entailed a potential risk of a more severe injury. The accident type (fall to lower level, collision with falling, flying or other moving objects) and production type (kitchen cupboards) affected the potential severity of the injuries (table 7).

\section{Safety countermeasures}

The need for least one safety countermeasure was identified for 149 injuries (70\% of all injuries), two countermeasures for 31 injuries $(14 \%)$, and three countermeasures for 1 injury. Altogether 214 countermeasures were identified (ie, an average of one countermeasure per injury). Of these, $40 \%$ were directed at improving the safety behavior of workers, and $26 \%$ at improving workplace procedures. Seventeen percent of all the countermeasures were directed at improving existing technology, and $17 \%$ concerned the work environment. The most
Table 5. Variables statistically significant in the analysis of covariance of the actual severity of the occupational injuries that occurred in the furniture factories.

\begin{tabular}{|c|c|c|c|}
\hline \multirow[t]{2}{*}{ Variable } & \multirow{2}{*}{$\begin{array}{l}\text { Injuries } \\
(\mathrm{N})\end{array}$} & \multicolumn{2}{|c|}{ Sick leave } \\
\hline & & $\begin{array}{l}\text { Crude mean } \\
\text { (d) }\end{array}$ & $\begin{array}{c}\text { Adjusted } \\
\text { mean } \\
\text { (log-scale) }\end{array}$ \\
\hline \multicolumn{4}{|l|}{$\begin{array}{l}\text { Type of injury } \\
P=0.0001^{\mathrm{a}}\end{array}$} \\
\hline $\begin{array}{l}\text { Fracture } \\
\text { Strain } \\
\text { Cut } \\
\text { Loss of fingertip } \\
\text { Contusion } \\
\text { Burn } \\
\text { Acid injury } \\
\text { Other }\end{array}$ & $\begin{array}{r}8 \\
47 \\
79 \\
2 \\
73 \\
3 \\
1 \\
1\end{array}$ & $\begin{array}{r}46.5 \\
9.1 \\
5.5 \\
27.0 \\
6.1 \\
12.3 \\
7.0 \\
18.0\end{array}$ & $\begin{array}{l}1.58 \\
0.76 \\
0.65 \\
1.36 \\
0.71 \\
1.05 \\
1.42 \\
1.91\end{array}$ \\
\hline \multicolumn{4}{|l|}{$\begin{array}{l}\text { Injured body part } \\
P=0.0002^{a}\end{array}$} \\
\hline $\begin{array}{l}\text { Head } \\
\text { Face } \\
\text { Back } \\
\text { Chest } \\
\text { Body } \\
\text { Eye } \\
\text { Finger } \\
\text { Hand } \\
\text { Shoulder, arm } \\
\text { Toe } \\
\text { Foot, ankle } \\
\text { Hip, knee, leg }\end{array}$ & $\begin{array}{r}4 \\
4 \\
23 \\
5 \\
6 \\
9 \\
92 \\
29 \\
7 \\
8 \\
22 \\
5\end{array}$ & $\begin{array}{r}4.5 \\
3.3 \\
8.4 \\
7.2 \\
17.3 \\
1.2 \\
8.9 \\
9.5 \\
13.9 \\
3.9 \\
7.8 \\
5.2\end{array}$ & $\begin{array}{l}0.54 \\
0.95 \\
1.38 \\
1.42 \\
1.34 \\
0.70 \\
1.30 \\
1.28 \\
1.61 \\
1.10 \\
1.31 \\
1.23\end{array}$ \\
\hline \multicolumn{4}{|l|}{$\begin{array}{l}\text { Type of production } \\
P=0.0281^{\text {a }}\end{array}$} \\
\hline $\begin{array}{l}\text { Upholstery } \\
\text { Wooden } \\
\text { Kitchen } \\
\text { Combined }\end{array}$ & $\begin{array}{l}33 \\
98 \\
64 \\
19\end{array}$ & $\begin{array}{r}7.1 \\
8.8 \\
7.9 \\
10.3\end{array}$ & $\begin{array}{l}1.19 \\
1.09 \\
1.07 \\
1.36\end{array}$ \\
\hline \multicolumn{4}{|l|}{$\begin{array}{l}\text { Company size } \\
P=0.0345^{\mathrm{a}}\end{array}$} \\
\hline $\begin{array}{l}\text { Small } \\
\text { Medium } \\
\text { Large }\end{array}$ & $\begin{array}{r}21 \\
69 \\
124\end{array}$ & $\begin{array}{r}10.7 \\
10.6 \\
6.8\end{array}$ & $\begin{array}{l}1.23 \\
1.22 \\
1.08\end{array}$ \\
\hline All & 214 & 8.4 & . \\
\hline
\end{tabular}

a Test for the hypothesis that all the adjusted category means of the variable are equal.

Table 6. Actual severity of the occupational injuries and the risk for the most severe potential injuries in the furniture factories. [class $1=$ small or negligible: sick leave $<3 \mathrm{~d}$ or no sick leave; class 2 = slight: sick leave 3-30 d (eg, cuts, strains, fractured finger); class $3=$ considerable: sick leave $1-12$ months or partial permanent disability $<10 \%$ (eg, fractured leg or arm, loss of forefinger); class $4=$ severe: sick leave $>12$ months or permanent disability of $10-60 \%$ (eg, loss of thumb or hand); class $5=$ critical: total permanent disability (eg, loss of legs) $>60 \%$ or fatality (21)]

\begin{tabular}{lcccccc}
\hline $\begin{array}{l}\text { Severity of } \\
\text { actual injuries }\end{array}$ & \multicolumn{4}{c}{ Most severe potential injuries } & Total \\
\cline { 2 - 6 } & $\begin{array}{c}\text { Class 1 } \\
\text { (N) }\end{array}$ & Class 2 & Class 3 3 & Class 4 & Class 5 & (N) \\
(N) & (N) & \\
\hline Class 1 & 23 & 33 & 13 & - & - & 69 \\
Class 2 & $\cdot$ & 89 & 41 & 2 & 1 & 133 \\
Class 3 & $\cdot$ & $\cdot$ & 12 & - & - & 12 \\
\hline Total & 23 & 122 & 66 & 2 & 1 & 214 \\
\hline
\end{tabular}


Table 7. Variables statistically significant in the analysis of covariance of the potential severity of occupational injuries in the furniture factories.

\begin{tabular}{|c|c|c|c|}
\hline \multirow[t]{2}{*}{ Variable } & \multirow{2}{*}{$\underset{(N)}{\text { Injuries }}$} & \multicolumn{2}{|c|}{ Potential severity } \\
\hline & & Crude mean & $\begin{array}{l}\text { Adjusted } \\
\text { mean }\end{array}$ \\
\hline \multicolumn{4}{|l|}{$\begin{array}{l}\text { Type of accident } \\
P=0.0014^{a}\end{array}$} \\
\hline $\begin{array}{l}\text { Fall to lower level } \\
\text { Fall to same level } \\
\text { Hurting oneself }\end{array}$ & $\begin{array}{l}6 \\
7\end{array}$ & $\begin{array}{l}3.00 \\
2.43\end{array}$ & $\begin{array}{l}2.98 \\
2.41\end{array}$ \\
\hline $\begin{array}{l}\text { on an object } \\
\text { Collision with falling, flying }\end{array}$ & 52 & 1.94 & 1.95 \\
\hline & 46 & 2.37 & 2.39 \\
\hline $\begin{array}{l}\text { machine part or tool } \\
\text { Moving vehicle }\end{array}$ & $\begin{array}{r}59 \\
1\end{array}$ & $\begin{array}{l}2.31 \\
3.00\end{array}$ & $\begin{array}{l}2.33 \\
2.81\end{array}$ \\
\hline Strenuous movement & 38 & 2.18 & 2.18 \\
\hline Other & 5 & 2.20 & 2.18 \\
\hline \multicolumn{4}{|l|}{$\begin{array}{l}\text { Type of production } \\
P=0.0186^{\mathrm{a}}\end{array}$} \\
\hline Upholstery & 33 & 2.21 & 2.41 \\
\hline Wooden & 98 & 2.10 & 2.27 \\
\hline Kitchen & 64 & 2.44 & 2.59 \\
\hline Combined & 19 & 2.26 & 2.34 \\
\hline All & 214 & 2.23 & . \\
\hline
\end{tabular}

important single recommended countermeasures were $(\mathrm{N}=214)$ use of safety gloves $(12 \%)$, better housekeeping $(8 \%)$, improvement of machine guarding $(8 \%)$, improvement of passageways $(8 \%)$, better planning of work $(7 \%)$, use of auxiliary equipment or work tools $(6 \%)$, proper work method or proper use of machine $(6 \%)$, improved carefulness $(5 \%)$, enlargement of work space $(5 \%)$. To our knowledge, only $6 \%$ of the identified countermeasures were implemented. However, this figure does not include the possible better use of personnel safety devices.

\section{External validity of the study material}

According to official occupational accident statistics, 1019 accidents leading to at least $3 \mathrm{~d}$ of incapacity to work occurred in the Finnish furniture industry in 1987 (15). The distributions of the sources of injury in the official statistics and in the study material were statistically equal $(\mathrm{P}<0.8)$.

\section{Discussion}

During the registration period, every seventh worker in Finnish furniture factories was inflicted by an onsite injury that led to at least first-aid in some health care center. The injuries in this study were slight. They were cases requiring medical treatment only or temporary total disabilities, including two cases involving slight partial loss of fingertips.
According to the official accident statistics of 1987 , the disabling injury rate in the Finnish furniture industry was 8.4 injuries (resulting in at least $3 \mathrm{~d}$ of incapacity to work) per 100 workers per year. In this study the corresponding injury rate was slightly less, being 7.2. The occupational injury risk differed significantly according to the production type and size of the furniture companies. Statistical differences according to accident type were not found. The disabling injury rate was highest in large companies and lowest in small ones. This result differs from the findings in other studies, which have reported that small and large companies have a lower injury rate than middle-sized companies (25). In this study it may be possible that not every injury in the small companies, especially minor ones, had been reported to the researchers. In the large companies, the data collection functioned better. The disabling injury rate was twice as high in this study as in similar studies in Swedish or Norwegian furniture factories. The rates were comparable because the studies were conducted with similar methods in these countries (11).

Accidents involving machines comprised half of all the injuries. The most common machine types were saws, drills, and millers. This result has been verified also in earlier studies (14). The injuries occurred mainly during normal production work (ie, in the use of machines and in materials handling).

The factors affecting the actual severity of the injuries differed from those affecting the potential severity of the injuries. The nature of the injury was the most important factor affecting the actual severity, whereas the type of accident mostly affected the potential severity of injuries. Especially falls and moving vehicles seemed to involve a potential risk for severe injuries. All in all, almost every second accident could have led to a more severe injury, and one accident $(0.5 \%$ of all injuries) to a critical consequence (ie, fatality). In a Finnish steel factory, $11 \%$ of the investigated injuries could have led to a critical consequence (21). There is a difference in the risk of a potentially severe injury in these two branches of industry. From the viewpoint of accident prevention, the investigation of minor injuries is important because, in other situations, similar accidents might have led to more severe injuries.

The foremen and the injured persons were able to identify the causal factors of the accidents and the needed safety countermeasures for almost every injury. The accidents could not be investigated in more detail because of limited resources. The researchers interviewed only the injured persons and their foremen. This restriction may have influenced the distribution of identified causal factors and countermeasures because only the most distinct and easily recalled factors and measures had been reported. For example, the use of personal protective devices might not necessarily be the best countermea- 
sure if the accidents could have been investigated in more detail. However, the personnel in furniture factories had knowledge and competence to identify accident causal factors and to consider proper countermeasures.

The recommended countermeasures were implemented for only $6 \%$ of the injuries, although they had been identified for $85 \%$ of the injuries. Attention should be directed more to the assumption of safety responsibility, and to the improvement of safety motivation in furniture factories, so that identified safety countermeasures would also be carried out in practice.

\section{Acknowledgments}

The study was financed by the Finnish Work Environment Fund, the Finnish Institute of Occupational Health, and the Academy of Finland. The steering group of the study was the Work Environment Group of the Finnish Wood Industry.

Tuula Räsänen, BSc, was in charge of the data collection in the furniture factories. Pertti Mutanen, MSc, assisted with the statistical analyses, and Terttu Kaustia, MA, revised the language of the manuscript. Finally, I especially wish to thank all the furniture factories that participated in the study.

\section{References}

1. Hagwood PE. An occupational health study of the North Carolina furniture industry. Raleigh (NC): Department of Environmental Sciences and Engineering, University of North Carolina, 1975.

2. Haakonsen H, Larsen SE, Lange E, Ebbestad AV. Arbeidsmiljø i møbel- og treindustrien [The working environment in the furniture and woodworking industry]. Vern og velferd 1981;5:21-37.

3. Laitinen, H. Tapaturmariskit sahateollisuudessa [Accident risks in woodworking industry]. Työterveyslaitoksen tutkimuksia 1983;2:95-104.

4. Ma WSA, Wang MJJ, Chou FS. Evaluating the mechanical injury problem in the wood-bamboo furniture manufacturing industry. Int J Ind Ergon 1991;4:347—55.

5. Acheson ED, Pippard EC, Winter PD. Mortality of English furniture makers. Scand J Work Environ Health 1984;4:2117.

6. Novak JJ, Hain JR. Furniture stripping vapor inhalation fatalities: two case studies. Appl Occup Environ Hyg 1990;12: $843-7$.

7. Schmieder $\mathrm{H}$, Wehlte $\mathrm{W}$. Danger points and safety measures in the processing of polyurethane and latex foam in furniture upholstery. Unser Brandschutz 1971;1;11-6.
8. Occupational Safety and Health Administration. Occupational safety and health programs for furniture manufacturers. Raleigh (NC): North Carolina Department of Labor, 1975.

9. Woodworkers' Accident Prevention Association. Furniture manufacturing safety and health guide for employers joint health and safety committees supervisors. Toronto: Industrial Accident Prevention Association, 1985.

10. Health and Safety Executive. Furniture and woodworking health and safety 1977. London: Health and Safety Executive, 1979.

11. Söderqvist A, Rundmo T, Aaltonen M. Cost of accidents in the Nordic furniture industry - a comparison. Stockholm: The Institute for Human Safety \& Accident Research, 1989. Factum no 17

12. Söderqvist A, Persson I. Olycksfallskostnader i svensk möbelindustri [Costs of accidents in the Swedish furniture industry]. Stockholm: The Institute for Human Safety \& Accident Research, 1988. Factum no 15.

13. Rundmo, T. Kostnader ved ulykker i norsk møbelindustri [Costs of accidents in the Norwegian furniture industry]. Trondheim: Stiftelsen for industriell og teknisk forskning ved Norges tekniske høgskole (SINTEF), 1988. Resultatrapport STF75 A88027.

14. Varonen U, Tuompo E. Puuntyöstökonetapaturmat [Accidents in woodworking machines]. Tampere (Finland): Työsuojeluhallitus, 1985. Tutkimusraportti 49.

15. The Board of Labour Protection. Industrial accidents. Tampere (Finland): Statistics Finland, 1987.

16. Aaltonen $\mathrm{M}$, editor. Työtapaturmat ja niistä aiheutuvat kustannukset huonekaluteollisuudessa [Occupational accidents and their costs in the Finnish furniture industry]. Työ ja ihminen $1989 ; 3: 175-236$

17. Tuominen R, Saari J. A model for the analysis of accidents and its application. J Occup Accid 1982;4:263-73.

18. Heinrich HW, Peterson D, Roos N. Industrial accident prevention. New York (NY): McGraw-Hill Book Company, 1980. Fifth edition.

19. Kjellén $U$. The deviation concept in occupational accident control - definition and classification. Accid Anal Prev 1984:4:289-306.

20. Hendrick K, Benner L. Investigating accidents with STEP. New York (NY): Marcel Dekker Inc, 1987.

21. Laitinen H. Determining risk potential through accidents and near-accidents: an empirical study in a steel factory. Lappeenranta (Finland): Lappeenrannan teknillinen korkeakoulu, 1984. Research papers 9.

22. Anderson S, Auquier A, Hauck WW, Oakes D, Vandaele W, Weisberg HI. Statistical methods for comparative studies: techniques for bias reduction. New York (NY): John Wiley \& Sons, 1980 . Wiley series in probability and mathematical statistics.

23. Statistics and Epidemiology Research Corporation (SERC). EGRET software and reference manual. Seattle (WA): SERC Inc, 1993.

24. SAS Institute. The SAS system for Windows ver. 3.10 (release 6.08). Cary (NC): SAS Institute Inc, 1991-1992.

25. Grimaldi JV, Simonds RH. Safety management. 3rd edition. Homewood (IL): Richard D Irwin Inc, 1975.

Received for publication: 24 march 1995 